\title{
ECOCRITICISM VALUES IN THE INDONESIAN FOLKTALE TIMUN EMAS (GOLDEN CUCUMBER)
}

\author{
Retnowati $^{1}$; Endang Ernawati ${ }^{2}$; Akun ${ }^{3}$ \\ ${ }^{1,2,3}$ English Department, Faculty of Humanities, Bina Nusantara University \\ J1. Kemanggisan Illir III No. 45, Palmerah, Jakarta 11480, Indonesia \\ ${ }^{1}$ retnowati@binus.ac.id; ${ }^{2}$ ernaw@binus.edu; ${ }^{3}$ akun@binus.edu
}

\begin{abstract}
The article presented how to learn an Indonesian folktale entitled Timun Emas which related to the process of the environment. The elements of fiction in this folktale, the setting, was a clue in relating the nature and the human which was part of eco-criticism. This research presented the earth-centered approach to literary studies to see how nature was represented in this folktale, what role of the physical setting played in the plot, the values expressed in this folktale, how metaphor of the land influenced the way human treated it, how the concept of wilderness had changed over time, in what way literacy itself had affected humankind relationship to the natural world. It also analyzed the interconnections between culture and nature, specifically the cultural artifacts of language and literature, understanding the ethical system and use it to reform them. This research used a qualitative method which was based on library research. The theory of Glotfelty then was combined with Anthropocentrism to see the human as the center of the hemisphere and how they determine the ecosystem and the policy related to nature. It is concluded that Timun Mas is able to represent the Indonesian culture, human and nature relationship, as well as culture and nature relationship drawn from the values and belief in the folklore.
\end{abstract}

Keywords: eco-criticism, folktale, nature, human values

\section{INTRODUCTION}

Timun Emas (Golden Cucumber) is one of the Indonesian folktales which is very popular among the children, especially in East Java because the parents often tell their children about this story. This story tells about a poor old woman who lives alone. Then she goes to a giant and asks a child. The giant has said that he will give her a child with one condition that she will give the child to the giant when the child turns six years old. She does not think any longer and agrees with this agreement. Then the giant gives her the seed of cucumber to plant. Arriving home, she plants the seed and when the flower of the cucumber blooms, she finds a tiny little girl inside the flower. She is very happy finding her, brings her home, raising her, and named her Timun Mas (Golden Cucumber).

When the little girl is six years old, she remembers her agreement with the giant, but she is afraid of letting the tiny girl go to the giant. Then she prepares everything needed when the giant comes to take her. When the giant comes, she does not give the little girl to go with the giant. She has asked her to leave the house before the giant comes. The giant chases Timun Mas, but she throws some kinds of stuff which makes the giant not be able to catch her. There are some different natural phenomenon appears during the giant chases the girl. In the end, the giant sinks in one of the natural phenomenon caused by the throwing things of Timun Mas. She is saved from the giant.

As in other traditional literary work, Timun Mas has values and based on the synopsis. This value is related to the relation of human and nature. It is about how human uses nature to support their need. Since the study of eco-criticism is about the relation of human and nature which is related to the 
culture, this folktale represents the cultural values of Indonesian in the relation between human and nature. Problem formulations of this research to analyze are how the Indonesian values, the culturenature, and the human nature relationship represented in the story entitled Timun Mas.

The research only focuses on the character, setting, plot, and symbol of Timun Mas. These elements of fiction will be used to analyze the folktale using the theory of eco-criticism related to values, human, nature, and culture. The goal of this research is to learn the elements of the folktale in Timun Mas, such as the character, plot, and setting. It is also to know how the changing of the setting can show the values, the relation between culture and nature, as well as human and nature. The objective of the research is to develop people awareness in preserving environment and how to live a not-greedy life and peaceful among people.

Indonesian cultures are rich in folklore. The folklore is the mirror of the life of the human in the society. Folktales depict literary tradition in many cultures and are believed as culturally significant and morally valuable. In addition, folktales represent prototypes of later fictional developments (Masykuroh, 2016). The function of folklore, however, is to validate certain aspects of culture. Folk literature is not merely a carrier of cultural values; rather, it is also an expression of self-reflection. It merely not serves as a platform to hold high moral grounds without any relevance to present day reality; instead, writers use it as a commentary or satire on current political and social reality. In the modern academic world, folklores and folktales are studied to understand ancient literature and civilizations.

Some of the Indonesian folklores tell about the existence of the natural phenomenon or natural objects. It can be lakes, mountains, and other natural objects. According to Guller in Gonen and Guller (2011), the environmental issues in early childhood can take the form of the following themes; air, land, stones and minerals, water, energy materials and resources, plants and animals, human beings and communities, structures, and industrialism. Since this is about nature and human, this literary work can be analyzed through eco-criticism theory. According to Glotfelty and Fromm (1996), eco-criticism is simply defined as a study of the relationship between literature and the physical environment. It is to understand the human, nature, animal that represents the physical environment from the point of view of literary work. Thus, eco-criticism explains the relation between human and animal, or culture and nature which is seen from the perspective of literature.

Worster and other historians as cited in Glotfelty and Fromm (1996) are writing environmental histories, studying the reciprocal relationships between humans and land, considering nature not just as the stage upon which the human story is acted out, but as an actor in the drama. There are four series of adjoining and overlapping areas which move gradually from nature to culture which is called outdoor environment (Barry, 2009). The first series is area one (the wilderness). This area consists of deserts, oceans, and uninhabited continents where nature is still not touched by human hands or still uncontaminated by civilization. The second series is area two (the scenic sublime). This consists of forests, lakes, mountains, cliffs, and waterfalls where human is rarely seen, and the animals are still dependent on nature. The third series is area three (the countryside). It consists of hills, fields, and woods where humans are living together with nature. The fourth series is area four (the domestic picturesque). It consists of parks, gardens, and lanes where human already dominates the area, and the area of nature has already decreased.

Bertens (2009) also examines the representation of the original state of nature as well as landscape. Eco-criticism is not the representation of nature to the way the animal represented, but it is more about the representation of the landscape; the landscape of wilderness and the landscape of pastoral. It also looks at discourses on the concept of 'nature' and 'wilderness'. Furthermore, he has stated that it is the human decision to violate the nature or the wilderness or to protect the nature. This is because human culture is part of nature and human thinks that nature belongs to the culture. In ecocriticism, nature belongs to the human. Bull (as cited in Bertens, 2009) has stated that there four features which explain one of the founding father of eco-criticism theory. The first is the non-human environment 
which presents not only as a farming device. The second is the human interest which is not understood to be the only legitimate interest. The third is human accountability to the environment which is part of the text's ethical orientation. The fourth is some sense of the environment as a process rather than as a given.

While Waugh (2006) has stated that there is a movement in eco-criticism which is a collective term for the efforts of poor communities who defend themselves against the toxic waste, the air, the food, and water contamination which can harm them and make them lose their homeland. This is called the environmental justice movement. Eco-critics worry if nature as a cultural and ideological construct that is made by different groups gets much attention which can cause the neglect of nature as an objective, material, and vulnerable reality.

Dewi (2017) has stated that adults suppose to be careful of eco-education in children literature in order to appreciate the environment. It can be done by examining environmental stories such as fables, folklore, short stories from Asia, and make a project report on writing eco-education materials. Using Ecocriticism and Postcolonial perspectives, she finds that the stories contain depletion of the earth and natural resources, people's greediness, and preservation of the traditional wisdom. It is still anthro $\neg$ pocentric exists in some stories. It is an indication that there is the human-nature relationship in a balanced way. Animal stories dominate the narratives; however, the Asian stories have characteristics to campaign about the environment through its philosophy and values.

Sukmawan and Setyowati (2017) have found that there are 17 Indonesian folklores describe environmental messages such as catastrophe because of human's greed and misconducts to nature and the human that prevents it. Folklores are used to train the students to build awareness to the protection of the environment, to enrich the cultural literacy, cultivate respectful behavior, and critical thinking ability.

\section{METHODS}

This research uses a qualitative method which is based on library research and text analysis. The media to be analyzed in this research is a folktale entitled Timun Mas. This folktale is chosen because of its content which represents the Indonesian values. The theories used are eco-criticism by Glotfelty and Anthropocentrism to analyze the relationship between human and nature. Data collection is done by analyzing the intrinsic element of fiction which discusses the character, plot and setting, symbol, and theme. It is continued by extrinsic element analysis that applies eco-criticism and anthropocentrism theories to know the Indonesian values, the relation between culture and nature, as well as human and nature.

\section{RESULTS AND DISCUSSIONS}

Timun Mas is Indonesian folklore which contains Indonesian values and beliefs. Since this research is based on the theory of ecocriticism; therefore, the discussion will deal with the intrinsic elements of this folktale. They are character, plot, setting, symbol, and theme. All of these intrinsic elements will lead to the discussion of ecocriticism in Timun Mas. The character and characterization of Timun Mas are related to nature since the name represents something natural that comes from nature. The plot, how Timun Mas struggles to live, is also related to the environment. The setting, where the story takes place or happens, represents the different environment. There are also many symbols 
symbolizing nature and environment. How Timun Mas struggles to fight over the big giant becomes the theme of this story, also represents the struggle in the environment.

The next step is to apply the theory of ecocriticism by Glotfelty to study between literature and the physical environment, the human and nature, as well as the culture and nature. Glotfelty divides the environment into four kinds, and they are going to be discussed based on the settings in Timun Mas. The theory of Glotfelty then is combined with Anthropocentrism to see the human as the center of the hemisphere and how they determine the ecosystem and the policy related to nature. By this theory, it is to know if nature has the value of itself, it is worth to be protected. Biocentrism is also used in this discussion because based on this theory, anything and creative has value. It also considers the life and creature in the hemisphere are important and serious. All creatures have the value of themselves to deserve to get consideration and moral care. Nature needs to be treated morally, whether it is valuable for human or not.

The synopsis of Timun Mas presents that there are husband, Pak Simin, and his wife Bu Simin living in a village as farmers. They work very hard, from cultivating the soil to planting and growing the plants. Their life is good enough, but they have not had a child yet. They want to have one very much. Every day, they pray to God, hope that God will give them a child. This praying is done in a forest after they work at their farm. The giant who is the protector of the forest listens to the prayer of this couple. He wants to help them. He says to the couple with his thunderous voice, "Hei human, I will make your dream come true." Pak Simin and Bu Simin are trembling to listen to the loud voice of the giant. They are afraid of him that they are happy at the same time. They ask, "Will you make our dream come true?" and Bu Simin says impatiently, "Am I going to have a child?"

The giant will make their dream comes true with a requirement. The requirement is that they have to give the child to the giant at the age of 15 years. The couple agrees with the prerequisite of the giant. Then they go home, but there is a dilemma in them. On one side, they are happy because their dream about a child will come true. On the other hand, they are sad because if their child reaches 15 years old, they have to give the child to the giant. The giant's promise becomes true. A year later, $\mathrm{Bu}$ Simin delivers a baby girl. She is very beautiful and is named Timun Mas. Day by day, month by month, year by year, Timun Mas grows as a beautiful girl. Pak Simin and Bu Simin are happy of having a beautiful little daughter like Timun Mas, but they are also afraid of their promise to the giant when Timun Mas is 15 years old.

When Timun Mas reaches 15 years old, the giant comes for the promise. "This is the time for you to let the girl to me," said the giant. Bu Simin hides Timun Mas. She says to the giant that the girl has not been ready yet to let go with him. She asks the giant to come to another day. The day they promise, the giant comes again, but Bu Simin says that she has not been ready to go yet because she has already prepared her stuff. Bu Simin asks the giant to come again three days later. The day before the giant comes, Bu Simin and Pak Simin tell Timun Mas about their promise to the giant, and it cannot be delayed nor canceled. Listening to her parents'explanation, now Timun Mas knows why her parents are disappointed and worried. Timun Mas is a good who sympathized with the dilemma of her parents. As a child who is taught and obeyed her parents, she would let herself go with the giant. "No," said buSimin. "You will be eaten by him." "No my child, let him eat me because I am old. You stay here and live happily." Finally, after a long discussion, it is decided that Timun Mas has to leave the house before the giant comes. She has to go through the back door. Before Timun Mas leaves the house, she has to bring four items for them as protection. They are a seed of the cucumber, a thorn, sugar, and belacan (shrimp paste). BU Simin says, "Spread one by one if the giant was close to you." Timun Mas then leaves the house, and she keeps going as far as of the house she could.

When the giant is at the house of the Simin, he thinks that the little girl would appear from the front door. He is very angry realizing that Timun Mas runs away from her house, then he chases her. When the giant almost reaches Timun Mas, she throws her cucumber seed as instructed by her mother. 
When the seed fells to the ground, the place changes to be the forest of cucumber. Looking at the cucumber, the giant forgets about Timun Mas. He is busy eating all the cucumber. After he feels full, he remembers that he is chasing Timun Mas. He runs after her, but she has been some far from him. He keeps chasing and almost reaching her. When the giant is close to her, she throws her thorn, and the place quickly becomes the forest of plants with thorns, which is very tight, so it is hard to pass the plants. The giant is very angry looking at the plants. They become the obstacle for him to go faster chasing Timun Mas, but he has to pass it. The thorn hurts him a lot, and he is bleeding. He screams loudly, "Hai Timun Mas, where are you? Don't run." With much effort, the giant can pass through the forest which is full of plants with thorns.

Realizing that the giant is close to her, Timun Mas trembles because of fear, then throws the salt that she brings from home. The place then quickly changes to be the large ocean. Once again because of his supernatural powers, he could pass it. He swims, and he finally could chase Timun Mas. Timun Mas is very trembling because the giant is getting wilder and angrier. This might be caused that he is hungry and feels that he is messed around by Timun Mas. During chasing Timun Mas, the giant is screaming loudly. This time Timun Mas throws his last stuff her mother gives, the belacan (shrimp paste). As it fells to the ground, the place becomes a huge mud that spread around like ocean. This mud can suck anything that goes into it. Without considering its danger, he jumps into the mud and directly the mud sucks the giant to the bottom. After a long time, the giant does not appear again. Timun Mas goes home, and her parents are waiting for her. They feel relieved that their daughter is free from the giant. They are very happy looking at their only child saves. They live happily ever after.

The Indonesia values and beliefs in Timun Mas are freedom of belief, respect life in harmony, discussion and consensus, loyalty to parents, respecting other, civilized humanity, social justice to everyone, and surrender to Almighty God. Pluralism is a frame where there is the interaction of some group which respects and tolerates each other. These groups can live together without conflict of assimilation. Indonesia consists of diverse religions, cultures, and ethnicity spreading all over the continent. Pluralism is the concept of accepting this diversity. People know that diversity exists, so they try to maintain equality in one another. Indonesia strongly holds the national motto Bhinneka Tunggal $I k a$, which means unity in diversity. In this concept, everyone has the right to receive the same treatments and to feel included within the community. The people believe its important not to discriminate against others, and having different views is allowed. With those different views, they also earn the right to be respected.

In Timun Mas, there is an interaction between the Simins with the giant. Firstly, they respect each other because the giant can give what the Simins dream about. The Simins, on the other hand, agree with the requirement of the giant. Unfortunately, in the end, there is a conflict between them because of the different point of view. In Timun Mas, the Simins freely do what they believe, included praying to God, but they also believe that the giant will make their dream comes true. This is a kind of animism that is done by this couple, but they are free to do what they believe is true (Dananjaya, 1992). Respect life in harmony is about how people respects and tolerates each other in order that they can live in harmony. Indonesians highly believe that respect is an important value to maintain harmony and peace. Due to the different tribes and beliefs that exist in Indonesia, people may have different opinions on certain things. However, the differences do not tear them apart because Indonesians understand that being respectful to one another is necessary. They put aside those differences and respect other people's beliefs. Conflict is seen as unnecessary, and people try to avoid it. They do not want to cause a scene or trouble that might disturb the community. Once, even there are big differences in order to keep their own religions, Indonesians still try to be the democracy first to solve the problems together.

Communal means gotong-royong in Bahasa. Throughout the generations, this concept is proudly carried out on certain events. It is one of the values that Indonesian believes that it is important to always remain within society. It works when a group of people is working together to reach a certain goal. Other than that, it can also serve the purpose of helping one another. Communal work does not ask 
for anything in return. It strengthens the feeling of community among the people. Those who may not really know their neighbors well can begin to introduce themselves. The communal work reminds everyone that people need other people. They cannot always live only by themselves. In Timun Mas, the Simins and the giant cannot live in harmony because each of them has their own view, and they do not respect to each other (Dananjaya, 1992).

Discussion and consensus is part of Indonesian values and belief. Before doing something very important, they discuss what they are going to do. In this discussion, there is also consensus. In Indonesia, discussion and consensus are called musyawarah and mufakat. This is a value that people still uphold in different social environments such as school or family. The purpose is to come up with a solution for a specific problem by discussing. Once the people speak out their minds, they can reach a conclusion. The decision depends on what is best for the situation at hand. Therefore, people usually avoid selfishness because they understand it is for the common good. Since many people are involved, this discussion and consensus is a good way to see a problem from different perspectives too.

The common important rules of the discussion and consensus are; the decision is based on what the people agree on. Suggestions and advice are delivered in a way where people can easily understand them. Everyone must accept the result of the discussion. During the process of discussion, everybody understands that morality is an important factor when coming up with a solution. Unfortunately, in Timun Mas, there is no discussion about what they are going to do dealing with their dream. They just go to the forest to pray. Nevertheless, there is a consensus between the Simins and the giant about their commitment that the Simins have to let the child go with the giant at the age of 15 years. On the other hand, there is a discussion among the Simins about what should be brought by Timun Mas, and the steps she has to do when the giant chases her. In order to realize their plans, they have to train Timus Mas about stuff that she brings. It is all to escape from the giant, (Dananjaya, 1992).

The family is an important aspect in Indonesia. The people believe that one should understand how to respect parents from an early age. A reason for this is because parents provide everything that a child needs even when they are not yet born. It is common when a grown adult still lives with his or her parents. Even though they can provide for themselves, they still have the duty of taking care of the parents. The adult can also contribute to the welfare of the whole family. Loyalty to parents is a value that Indonesians take seriously. Timun Mas is a child who is very loyal to their parents. Knowing that their parents sacrifice their life to them so that she can live happily, she is touched and asks for the parents to let her go with the giant. She knows the dilemma in the family, whether to let her go with the giant or not, then she offers herself as the hostage of the giant, but her mother does not allow her to do it (Dananjaya, 1992).

Indonesians believe in the concept of respecting the elders. The elders are seen as wiser and experienced. Thus, the young ones must not display arrogance. Younger people are encouraged to show their respect for the elders in an open manner. This could be in the form of using polite languages when speaking directly with them or another way is to mind the body language. The young one must avoid rude gestures and shows the proper manner to the older person. This particular attitude shows the value of humbleness. Humbling oneself in the presence of an older person is a morally right thing to do. In this case, Timun Mas respects her family very much. She offers herself as the sacrifice. However, there no respect of the Simins to the giant, because they are afraid Timun Mas will have the miserable life with the giant (Dananjaya, 1992).

In Indonesia, people believe that nobody should be physically or spiritually restrained against his or her will. In addition, Indonesian also upholds the value whereby the people earn the right to be protected from unjust treatments. Nobody is allowed to be the subject of oppression. The people have the right to be treated fairly and accordingly. The people have equal chances to pursue their dreams and happiness while living in their communities. Furthermore, the people can also use the natural resources of the nation to improve their livelihoods. Every work and every effort has the purpose of improving the 
quality of the citizens. In result, people can attain prosperity. This belief is called Sumarah in Javanese cultures. Sumarah's attitude implies a total submissive attitude to God. Inner attitude will only manifest in people who have faith in the existence of the almighty God who gives life. As well as believe that the God has created the world in its own way.

There are some intrinsic elements in Timun Mas. They are character, plot, setting, symbol, and theme which contribute to the discussion related to the theory of ecocriticism. There are four characters in this folklore. They are Pak Simin, Bu Simin, Timun Mas, and the giant (Dananjaya, 1992). The plot begins with the exposition of the condition of the Simin whose life is not complete without a child. They pray to God, but the giant who listens to their pray makes their dream comes true. The conflict begins when the Simins realize their agreement with the giant has consequences. The rising conflict goes when the giant comes to the house of the Simins to take Timun Mas away with him. It is followed by the escape of Timun Mas from the giant. The climax is when the giant without considering the condition of the mud insisted on jumping to the mud in order to catch Timun Mas. The falling action is when the giant died slowly because he drowns in the mud (Dananjaya, 1992).

There are several different settings in Timun Mas. The first one is the village where the Simins live. This is a kind of ordinary village where the couple lives before and after they have a child. Timun Mas is also raised in this village. The second is the cucumber plantation. This arouses because Timun Mas throws the seed of cucumber; consequently, there appears the huge plantation of cucumber. This is the first step that prevents Timun Mas from the giant. The third is the plants full of thorns. The plants full of thorns come up because she throws the thorn. This huge area of plants hurts the giant and the second prevention for Timun Mas from the chase of the giant. The fourth is the ocean. This ocean arouses because she throws salt. Salt is from the sea, so when it is thrown, it is back to the previous form or the origin. This is the third prevention of nature to protect Timun Mas from the giant. The last setting is the mud. The area of mud comes up because she throws the belacan (shrimp paste). It is just like the mud which is smelly. Moreover, the mud is dangerous because it sucks everything fell into it. This is the last protection for Timun Mas from being caught by the giant (Dananjaya, 1992).

There are some symbols in Timun Mas. The first one is the name, Timun Mas. Name of Timun Mas is given to the little girl because she is tiny. Cucumber itself is a vegetable which makes the body fresh when people are eating it. It is the same as the meaning of the name Timun Mas that she gives the freshness in life for her parents. The coming of Timun Mas in the couple's life makes their life more cheerful and different from the previous time. So, Timun Mas is the symbol of hope of life that makes life more fresh and cheerful. The second is the giant. The giant is the symbol of greediness. Giant is bigger than the human being. This creature is never satisfied with what he has. He always wants more. He does not let Timun Mas free from him because it is his right to have her based on the agreement. His greediness leads him to his death.

The third is the seed of cucumber. It is a symbol that a small thing can make a big one. The small seed can make a huge plantation of cucumber that protects Timun Mas from the giant. The cucumber makes the giant forget Timun Mas temporarily because he is busy eating them. The fourth is the thorn. It symbolizes something hurt. When the plants full of thorn appear, they make the giant hard to reach Timun Mas because he has to pass the thorns which hurt his body. Actually, the giant should stop when facing something hurt, but he never stops till he gets what he wants. The fifth is salt. It symbolizes the flavor of life. Without salt, the food does not taste good and plain. So is life, it will be plain without salt. By throwing the salt, then finally becomes the ocean, it is actually a message from Timun Mas to stop chasing her because life is more beautiful for both when he stops doing what he wants. The sixth is the belacan (shrimp paste). The function of belacan for cooking is to give flavor, but this is stronger than salt. It symbolizes the last message to the giant that he has to stop chasing Timun Mas because it can be deadly if he still does what he wants. 
The theme of Timun Mas is always optimistic about facing the problems in life. The relation of culture and nature presented in Timun Mas, it is divided into four series; those are the area of wilderness, the scenic sublime, the countryside, and the domestic picturesque. The area of wilderness is shown in the story consists of deserts, oceans, and uninhabited continents where nature is still not touched by human hands or still uncontaminated by civilization. In Timun Mas, the area of wilderness is represented by the setting of the ocean which arises from the salt thrown by Timun Mas, and also a huge mud which comes up from the belacan. It is not inhibited by men. The second area is area two which is a scenic sublime. This consists of forests, lakes, mountains, cliffs, and waterfalls where human is rarely seen, and the animals are still dependent on nature. In Timun Mas, this area is included the forests where the giant lives and the plants which are full of thorns. The third series is area three or the countryside. It consists of hills, fields, and woods where humans are living together with nature. In Timun Mas, this area is where there are plants full of thorns, and the farm that the Simins have. The fourth series is area four (the domestic picturesque). It consists of parks, gardens, and lanes where human already dominates the area, and the area of nature has already decreased. Here is the village where the Simins live (Dananjaya, 1992).

The relation of human and nature in Timun Mas is when nature, which are the cucumber plantation, plants full of thorns, ocean, and mud contribute to the save of the child from the giant. The relation of human and nature in Timun Mas can be seen when the Simins think that nature can help them. The culture and nature relationship can be drawn from the values and belief in Timun Mas. The greediness of the giant can put him into disaster. This is like what the human being who firstly appreciate nature as something precious, but with the greediness of human, the environment will be damaged.

When Dewi (2017) concentrates more on fables, folklores short stories in Asian countries and use them as the project to teach writing and she found that those works contain depletion of the earth and natural resources, people's greediness, and preservation of the traditional wisdom, anthropocentric, ecocriticism, poscolonialism, human-nature relationship, Timun Mas is a folktale containing humannature, culture-nature, and human-culture relationship as part of ecocritism which is portrayed through the setting.

Sukmawan and Setyowati (2017) describe environmental messages such as catastrophe because of human's greed and misconducts to nature and the human that prevents through 17 folklores to train the students to build awareness to the protection of the environment, to enrich the cultural literacy, cultivate respectful behavior, and critical thinking ability, Timun Mas, instead of describing ecocriticism through the environmental setting, it is also an explanation about Indonesian values that people should learn; the respect of the human and culture relationship, human nature, as well as culture nature.

\section{CONCLUSIONS}

From the analysis and the theoretical background, it can be concluded that the folklore entitled Timun Mas is the representation of the Indonesian culture because of the character, the characterization, the settings, and the themes are described the culture that is available in Indonesia. The folklore represents human and nature relationship. It can be shown that people in that story (The Simins) adore nature and think that nature can help them. They rely on cucumber plantation, plants full of thorns, ocean, and mud that contribute to the save of the child which symbolizes hope from the giant that represents greediness. The culture and nature relationship can be drawn from the values and belief in folklore entitled Timun Mas. The greediness of the giant can put him into disaster. This is like what the human being who firstly appreciate nature as something precious, but with the greediness of human, the environment will be damaged. 
There is a limitation in this research in which it only focuses in one Javanese folktale and environment preservation in the rural area. Therefore, the values got from the analysis is rich with Javanese culture and belief.

Further research having media of Indonesian folktale, one of them is Timun Mas, it can be developed by analyzing many regional folktales, such as Danau Toba (North Sumatera), The origin of Palembang Name (South Sumatera), The Legend of n'Daung Snake (Bengkulu), The origin of Tangkuban Perahu Mount (West java), The origin of Sagu and Palem Trees (Central Sulawesi), and many other folktales in the Indonesian regions. At present, Indonesia is facing many environment issues, such as floods, forest fires, volcanic eruption, etc. that concern with human unawareness with their surroundings. Therefore, it is better for the next research to analyze the Indonesian Folktale focusing on the environmental study by applying some theories, such as Glotfelty, Anthroposentrism, and Ecocriticism which can be related to the Indonesian regulation on environment preservation.

\section{REFERENCES}

Barry, P. (2009). Beginning theory: An introduction to literary and cultural theory ( $3^{\text {rd }} \mathrm{Ed}$.). Manchester, UK: Manchester University Press.

Bertens, H. (2009). The literary theory the basic ( $2^{\text {nd }}$ Ed.). New York: Routledge.

Dananjaya, J. (1992). Cerita rakyat dari Kalimantan. Yogyakarta: Katalog BPAD Daerah Istimewa Yogyakarta.

Dewi, N. (2017). People and nature in Asian stories: Reading and writing materials for Eco-Education. Kata, 19(1), 39-46. https://doi.org/10.9744/kata.19.1.39-46.

Glotfelty, C., \& Fromm, H. (1996). The Eco-criticism reader landmarks in literary ecology. USA: University of Georgia Press.

Gonen, M., \& Guler, T. (2011). The environment and its place in children's picture story books. Procedia Social and Behavioral Sciences, 15(2011), 3633-3639.

Masykuroh, Q. (2016). Physical and verbal violence in Indonesian folktales retold in children's book. Kajian Linguistik dan Sastra, 1(1), 25-34. Retrieved from http://journals.ums.ac.id/index.php/KLS/article/viewFile/2475/1665.

Sukmawan, S., \& Setyowati, L. (2017). Environmental messages as found in Indonesian folklore and its relation to foreign language classroom. Arab World English Journal (AWEJ), 8(1), 298-308. Retrieved from https://dx.doi.org/10.24093/awej/vol8no1.21.

Waugh, P. (2006). Literary theory and criticism an Oxford guide. USA: Oxford University Press. 